\title{
PEMIKIRAN ISLAM DAN PROSES DINAMIKANYA
}

\author{
Ach. Syaikhu \\ Dosen Fakultas Tarbiyah, IAI Al - Falah As - Sunniyyah Kencong \\ ach.syaikhul@gmail.com
}

\begin{abstract}
Islam is a religion of rahmatan'alamiin, a necessity if the values of His teachings when transferred in the life of both individuals, family and community groups in the state will provide peace. This basic concept in its actualization requires thought that is ginius and sincere because of God. From here arises the dynamics of Islamic voting, it all happens because of the demands of Islamic leaders who wish that the teachings of Islamic values can be actualized well and peacefully in the midst of widespread life, to the level of life in the frame of nation and state. In this article, various thoughts in Islam have been presented: theological thinking / kalam which discusses the discovery or the Essence of Allah, Fiqh thought related to the rules of worship both mahdhoh and ghoiru mahdhoh, philosophy thinking critically and systematically and radically in understanding $\mathrm{Al}$ text -Qu'an and $\mathrm{Al}-\mathrm{Hadith}$, tasawuf thoughts that are oriented towards good and bad behavior in human life.
\end{abstract}

Keyword: Thought, Islam, Dynamics

\begin{abstract}
ABSTRAK
Islam adalah agama rahmatan'alamiin, sebuah keniscayaan kalau nilai-nilai ajaranNya ketika ditransfer dalam sebuah kehidupan baik individu, keluaga kelompok masyarakat dan dalam bernegara akan memberikan kedamaian. Konsep dasar ini dalam aktualisasinya membutuhkan pemikiran pemikiran yang ginius serta ikhlas karena Allah. Dari sini muncul dinamika pemikran Islam, itu semua terjadi karena tuntutan para tokoh tokoh Islam yang berkeinginan agar ajaran nilai nilai Islam dapat diaktualisasikan dengan baik dan damai di tengat tengah kehidupan secara meluas, sampai pada tataran kehidupan dalam bingkai berbangsa dan bernegara. Dalam artikel ini telah dipaparkan berbagai pemikiran dalam Islam yeitu : pemikiran teologi/kalam yang membahas tentang ketahitan atau ke Esaan Allah, Fiqh pemikiran terkait dengan tata aturan dalam ibadah baik mahdhoh maupun ghoiru mahdhoh, filsafat berfikir secara kritis sistematis dan radikal dalam memahami teks teks Al-Qu'an dan Al-Hadits, tasawuf pemikiran yang berorientasi pada prilaku baik dan buruk dalam kehidupan manusia.
\end{abstract}

Kata Kunci: Pemikiran, Islam, Dinamika

FaLASIFA, Vol. 10 Nomor 1 Maret 2019 | 129 
Ach. Syaikhu

\section{PENDAHULUAN}

Berbicara tentang pemikiran Islam tak lepas dari perkembangan pemikiran manusia, pemikiran manusia dapat dipelajari menjadi 4 golongan yaitu :

1. Pemikiran peudo ilmiah bertumpu pada aspek kepercayaan / mitos

2. Pemikiran awam ialah pemikiran orang dewasa yang mengguakan akal sehat

3. Pemikiran ilmiah bertumpu pada metode tertentu melakukan hipoteses dan lanjutkan penelitian untuk menguji kebenaranya

4. Pemikiran filosofis yang mengedepankan reflektif, analisis, deskriptif, penilaian penafsiran dan perekaan. ${ }^{1}$

Islam memiliki ciri pemikiran khas (beda dengan yang lain) pemikiran Islam berdasar pada wahyu atau penjelasan wahyu secara rinci di deskripsikan secara rasional sesuai dengan fitrah manusia, sedangkan pemikiran-pemikiran yang lain yang dalam perkembangyaa, baik dari agama-agama non samawi, ideologiideologi politik dan ekonomi, sosial budaya maupun teori-teori lebih didasarkan pada kejeniusan berfikir manusia yang melahirkannya sehingga kebenaranya relatif sekali. Dengan demikian, perlu dipahami bahwa adanya pemikiran Islam merupakan petunjuk bagi manusia di muka bumi ini. Oleh sebab itu, agar bisa memahami eksistensi pemikiran Islam sebagai petunjuk sikap dan amal perbuatan manusia, sangatlah perlu sekali memahami karakteristik pemikiran Islam. Dalam tulisan ini akan di bahas tentang aliran pemikiran Islam dan dinamikanya, meliputi fiqih, filsafat, teologi Islam dan tasawuf berikut tokoh-tokoh dan pemikirannya masing-masing.

\section{PEMBAHASAN}

\section{Perkembangan Pemikiran Islam}

Dalam proses perkembangan pemikiran islam, terdapat dalam tiga fase dan erat kaitannya dengan sejarah Islam. Pertama, akibat adanya pergolakan politik pada masa kekhalifahan Ali, menimbulkan perang Shiffin [antara Ali dan Muawiyah] dan perang Jamal [antara Ali dan Aisyah]. Adanya kasus perang ini menjadi faktor utama munculnya golongan Khawarji. Pergolakan politik itu diruncingkan oleh adanya pendapat Khawarij, bahwa orang-orang yang terlibat dalam perang Shiffin dan Jamal adalah berdosa besar dan kafir. Menetapkan Ali sebagai kafir sangat ditentang oleh sekelompok muslim yang selanjutnya disebut Syi'ah, sehingga terjadilah pertentangan hebat antara sesama muslim. Dalam setiapkemelut yang tidak menyenangkan itu, muncul sekelompok muslim yang berusaha menjauhkan diri dan tidak ingin melibatkan diri dengan selisih pendapat

\footnotetext{
${ }^{1}$ Hamdani Ihsan, Filsafat Pendidikan Islam, (Bandung; Pustaka Setia), 1
} 
tersebut, bahkan ada pula sekelompok muslim yang tidak ingin menyalahkan orang lain atau kelompok lainnya; namun dalam pada itu sempat ula meeka mengeluarkan faktanya bahwa segala hukum perbuatan manusia yang belum jelas nashnya, ditangguhkan hukumnya sampai diakhirat kelak. Mereka itu kelompok Murjỉah.

Kedua, akibat ekspansi Islam ke Barat sampai ke Spanyol dan Perancis, ke Selatan sampai ke Sudan, Ethiopia dan seterusnya, ke Timur sampai India dan seterusnya. Dan ke Utara sampai ke Rusia. Ekspansi yang dilakukan oleh Islam, ternyata tidak hanya berdampak pada penyebaran ajaran saja, tetapi juga semakin memperkaya khazanah kebudayaan Islam. Hal ini dikarenakan akulturasi budaya Arab-Islam dengan budaya-budaya lokal daerah yang ditaklukkan.

Salah satu budaya tau tradisi yang pada akhirnya banyak terserap dan teradopsi oleh Islam adalah tradisi Yunani danHellenistiknya yang bersifat spekulatif. Perembesan budaya ini disamping karena interaksi kaum muslimin dengan orang-orang yang mempelajari tradisi spekulatif Yunani, juga karena penerjemahan secara besar-besaran khazanah intelektual Yunani ke dalam bahasa Arab pada masa Abbasiyyah.

Ketiga, akibat adanya perubahan masyarakat dari masyarakat Tradisional menjadi masyarakat modern, dari pandangan cakrawala berpikir yang regional menjadi yang lebih luas lagi. Kehidupan pribadi makin lama makin kompleks, menimbulkan masalah-masalah baru yang memerlukan pemecahan.

Ketiga faktor di atas memberikan pengaruh kuat bagi pertumbuhan dan perkembangan pemikiran dalam Islam, di samping tentu saja banyaknya sugesti berupa ayat-ayat yang menganjurkan tentang pengembangan kemampuan berpikir. Ada banyak ayat dalam al Qur'an yang baik secara langsung maupun tidak mendesak manusia untuk berpikir, merenung atau bernalar.

Selain perintah untuk menggunakan akal untuk berpikir, merenung, dan sejenisnya, al Qur'an juga menggunakan kata 'ilm dalam berbagai bentuk dan artinya sebanyak 854 kali. Antara lain sebagai proses pencapaian pengetahuan dan objek pengetahuan. Di dalam al Qur'an juga terdapat lebih dari 750 ayat yang menunjukkan kepada fenomena alam, dan manusia diminta untuk dapat memikirkannya agar dapat mengenal Tuhan lewat tanda-tanda kekuasaan-Nya.

Lebih lanjut, Ibnu Khaldun mencatat bahwa kunci dari maraknya peradaban Islam adalah tradisi kebebasan berpikir dan independensi ulama dari ranah politik. Dalam hal ini, menurutnya, ulama adalah sosok yang mampu melakukan analisis dan menangkap makna-makna yang tersirat, baik dalam ranah sosial maupunteks keagamaan. Konsentrasi para ulama dalam ranah pengetahuan keagamaan, dalam sejarah peradaban Islam, telah membuktikan lahirnya 
Ach. Syaikhu

peradaban yang sangat adiluhung serta membawa pada pencerahan yang dapat dirasakan masyarakat di seantero dunia. Buah dari itu semua, pemikiran Islam telah menjadi gerbang pencerahan bagi Eropa dan Barat.

Sejarah telah membuktkan bahwa Islam telah menanamkan pondasi keilmuan di Spanyol, sehingga telah mengankat harkat martabat sepanyol menjadi gudangnya pengetahuan di benua Eropa, hanya karena kefanatikan agama, sehingga orang Eropa mengusir cendikiawan muslim keluar dari daerahnya, sekiranya hal ini tidak dilakukanya, maka masyarakat sepanyol akan lebih maju seabat dari pada sekarang ini. ${ }^{2}$ Karena itu, perlu kita menghidupkan kembali tradisi intelektual yang bebas, dialogis, inovatif, kreatif. Ibnu Rushd dalam Fashl al- Maqal bi ma bayn al-Hikmah wa al-Syari’ah min al-Ittishal [1982], mempunyai pesan menarik, bahwa hikmah, penalaran, dan filsafat adalah sahabat agama [syariat], dan saudara sesusuan. Agama dan kebebasan berpikir merupakan dua mata uang logam yang tidak bisa dipisahkan. Bahkan Al Qur'an dalam puluhan ayatnya menyebutkan pentingnya berpikir.

\section{Orientasi Historis Dinamika Pemikiran Islam}

Henri Berr dan Lucian Febvre mengemukakan pendapatnya bahwa tujuan akhir dari pada ahli sejarah adalah bukan sekedar mengetahui kelompok tertentu dari pada manusia dalam periode periode tertentu tetapi yang terutama adalah keadaan perikemanusiaan dalam keseluruhanya. ${ }^{3}$

Keberadaan dan perkembangan ilmu-ilmu Islam dimulai sejak kerasulan Nabi Muhammad SAW. Pusaran ilmu itu ialah al Qur'an dan sunnah atau hadis yang kemudian melahirkan berbagai cabang ilmu. Situasi ini didukung oleh perkembangan bahasa Arab yang telah digunakan jauh sebelum masa kerasulan Nabi Muhammad SAW, sehingga posisi bahasa Arab mengambil peran penting bagi perkembangan ilmu Islam selanjutnya. Kondisi seperti ini disebabkan oleh sumber ilmu Islam yang menggunakan bahasa Arab sebagai medium komunikasi ke wilayah publik.

Adanya ekspansi umat Islam ke berbagai wilayah turut memperkaya khazanah intelektual muslim. Berbagai keilmuan Islam pun lahir sebagai bagian dari proses interaksi Islam dengan budaya-budaya lain, seperti Yunani, Persia, India, dan lain sebagainya. Lahirnya bidang keilmuan seperti filsafat, ilmu kalam, dan tasawuf tidak bisa dilepaskan dari interaksi-interaksi tersebut.

${ }^{2}$ Samsul Nizar, Sejarah Pendidikan Islam, (Solo; Kencana Prenada Media Gurp, 2013), 97

${ }^{3}$ H. Soekarno Drs dan Ahmad Supardi, Sejarah dan filsafat pendidikan Islam, (Bandung; Angkasa, 2001), 76

132 | FaLASIFA, Vol. 10 Nomor 1 Maret 2019 
Berikut ini akan dipaparkan dinamika beberapa varian pemikiran Islam, yang merupakan khazanah Islam yang senantiasa harus terus dipelihara dan dijaga keberadaannya, serta dikembangkan sesuai dengan perubahan yang menyertai perputaran dunia ini.

\section{Bidang Kalam [Teologi]}

Secara teologis tidak ada satu makhlukpun didunia ini yang tidak musnah dan berakhir, kecuali hanya dialah Allah SWT yang Maha Esa (al-Wahid), Maha raja (al-Malik). ${ }^{4}$ Kalam secara harfiah berarti pembicaraan. Istilah ini merujuk pada sistem pemikiran spekulatif yang berfungsi untuk mempertahankan Islam dan tradisi keislaman dari ancaman maupun tantangandari luar. Para pendukungnya, mutakallimun, adalah orang-orang yang menjadikan dogma atau persoalanpersoalanteologis kontroversial sebagai topik diskusi dan wacana dialetik, dengan menawarkan bukti-bukti spekulatif untuk mempertahankan pendirian mereka.

Definisi di atas nampaknya mengamini paparan Ibn Khaldun, yang menyatakan bahwa teologi atau kalam adalah ilmu yang mempergunakan buktibukti logis dalam mempertahankan akidah keimanan dan menolak pembaharu yang menyimpang dalam dogma yang dianut kaum muslimin pertama dan ortodoks Muslim. Para ulama sepakat bahwa tauhid adalah dasar utama dan pertama dalam ajaran Islam. Ketauhidan zaman Nabi ditanamkan oleh beliau melalui sikap dan tingkah laku bertauhid, yang apabila ada suatu masalah, bisa langsung ditanyakan kepada Nabi.

Isu pertama yang berakibat langsung pada keretakan masyarakat Muslim sesaat setelah wafatnya Nabi Muhammad saw. adalah perkara keabsahan pengganti Nabi saw. atau khalifah. Setelah khalifah Utsman ibn 'Affan terbunuh pada 656, isu pengganti Nabi saw. ini semakin mengemuka. Puncaknya, bentrokan antara pendukung 'Al ibn Thalib yang juga menantu nabi saw. dan Mu'awiyah sebagai kerabat khalifah yang terbunuh dan Gubernur Damaskus tak bisa dielakkan.

Sebagian umat Islam telah berani membuat analisis tentang pembunuhan Utsman tersebut, apakah si pembunuhnya berdosa ataukah tidak, bahkan tidak sampai di situ saja, tetapi juga dianalisis siapa yang menggerakkan tangan si pembunuh itu, apakah manusia sendiri ataukah Tuhan, hal ini, yang mungkin menjadi cikal bakal tumbuhnya paham Jabariah dan Qadariah.

Perselisihan umat Islam tersebut di atas terus berlanjut, hingga berpuncak pada peristiwa arbitrase, yaitu upaya penyelesaian sengketa antara Ala bin Abi

${ }^{4}$ Prof. Dr Muhammad Djakfar SH., M.Ag, Teologi Ekonomi Membumikan Titah Langit di Ranah Bisnis, (Malang; UIN Malang, 2010), 80

FalASIFA, Vol. 10 Nomor 1 Maret 2019 | 133 
Ach. Syaikhu

Thalib dan Mu'awiyah bin Abi Sufyan pada perang Shiffin dan perselisihan Ali ibn Abi Thalib dengan Aisyah pada perang Jamal. Peristiwa-peristiwa ini cukup banyak andilnya dalam melahirkan aliran atau mazhab dalam ilmu kalam [teologi].

Dalam perang Shiffin terjadi perdamaian atau tahkim antara pihak Ali dan Mu'awiyah, akan tetapi perdamaian tersebut tidak dapat diterima oleh sebagian pengikut Ali ibn Abi Thalib. Mereka itu dipelopori oleh Asy'ts ibn Qayis yang dalam perkembangan selanjutnya mereka itu disebut Khawarij. Kelompok Khawarij berfatwa bahwa orang yang terlibat dengan tahkim, baik menyetujui dan apalagi melaksanakannya dihukumkan berdosa besar dan setiap orang yang berdosa besar meninggal dunia tanpa tobat, maka itu adalah kafir. Salah satu alasan mereka karena tidak atau ingkar menjalankan kewajibannya sebagai seorang muslim.

Penentuan seseorang kafir atau tidak kafir bukan lagi soal politik, tetapi soal teologi. Kafir adalah orang yang tidak percaya, lawannya mu'min artinya orang yang percaya. Kedua istilah ini dalam al Qur'an biasanya berlawanan. Kata kafir yang ditujuan pada golongan di luar Islam, Oleh Khawarij dipergunakan dengan makana yang berbeda, yaitu untuk golongan yang berada dalam Islam sendiri.

\section{Bidang Fikih}

Munculnya kesadaran umat, terutama dalam dunia fiqh, tidak terjadi dalam sekali waktu, tetapi berproses panjang mengikuti alur perjalanan waktu dan luasnya wilayah dimana umat Islam itu berada. Hal ini menandakan bahwa fiqih punya karakter merespon gerak perubahan waktu dan tempat. ${ }^{5}$

Dalam perkembangan terakhir ini, meskipun masih samar-samar, kita menyaksikan munculnya kegairahan baru dikalangan para ulama dalam merespon perkembangan baru. Mereka menawarkan fiqih perkembangan dan juga menampakkan koncennya yang besar terhadap kepedulian sosial. Karenanya dalam hal ini banyak hal, mereka mengajukan pendekatan "transformatif" dalam memahami fiqih dan mencari relefansinya dengan persoalan persoalan kekinian. Fuqoha dipandang gagal jika tidak memperhatikan kebutuhan masyarakat dalam perkembangan yang sedimikian rupa, sehingga muncul kesenjangan antara fiqih secara teoritis dengan kenyataan masyarakat secara praktis. Pendekatan ini mengajar pada suatu pemahaman yang lebih dinamis dan tidak kaku, yaitu dengan menggabungkan pemahaman tarikh tasyri` dengan sosiologi hukum.

\footnotetext{
${ }^{5}$ Saifuddin Mujtaba, Ilmu Fiqih Sebuah Pengantar, (Jember; STAIN Jember Press,
} 2012), 108

134 | FalASIFA, Vol. 10 Nomor 1 Maret 2019 
Islam sebagaimana dikenal, mulai dari Madinah merupakan negara dan sebagai negara tentunya harus mempunyai lembaga hukum, untuk mengatur hidup kemasyarakatan warganya. Hukum yang dipakai dalam Islam berdasar pada wahyu, dan kalau diperhatikan sejarah turunnya wahyu, akan kelihatan bahwa ayat-ayat yang mengandung soal-soal hidup kemasyarakatan memang diturunkan di Madinah. Ayat-ayat yang mengandung dasar hukum, baik ibadah maupun hidup kemasyarakatan, disebut ayat ahkam.

Pada masa Nabi, karena segala persoalan dikembalikan kepada Nabi untuk menyelesaikannya, Nabi lah yang menjadi satu-satunya sumber hukum. Segala ketentuan hukum yang dibuat Nabi itu sendiri bersumber pada wahyu dari Tuhan. Pada masa sahabat, daerah yang dikuasai Islam bertambah luas dan termasuk ke dalamnya daerah-daerah di luar Semenanjung Arabia yang telah mempunyai kebudayaan tinggi dan susunan masyarakat yang bukan sederhana, diperbandingkan dengan masyarakat Arabia ketika itu. Dengan demikian, persoalan-persoalan kemasyarakatan yang timbul didaerah-daerah baru itu lebih sulit penyelesaiannya dari persoalan-persoalan yang timbul di masyarakat Semenanjung Arabia sendiri.

Untuk mencari penyelesaian bagi soal-soal baru itu, para Sahabat kembali kepada al Qur'an dan Sunnah. Tetapi, sebagaimana diketahui ayat ahkam berjumlah sedikit dan tidak semua persoalan yang timbul dapat dikembalikan kepada al Qur'an atau Sunnah Nabi, maka untuk itu Khalifah dan sahabat mengadakan ijtihad. Proses ijtihad pada aspek hukum ini semakin dibutuhkan dengan pada fase-fase selanjutnya. Seiring dengan banyaknya mujtahid [pelaku ijtihad], maka produk yang dihasilkannya pun sangat beragam.

\section{Bidang Filsafat}

Filsafat dan agama berbicara tentang hal yang sama,yaitu manusia dan dunianya. Apabila yang satu membawa kebenaran yang berasal dari Sang Pencipta Manusia dan dunianya itu, dan yang lainnya dari akal manusia yang selalu diliputi ketidakpastian sehingga kebenaranya sangatlah relatif sekali. Filsafat adalah alam berfikir, sebagai suatu perbincangan mengenahi segala hal secara sistematis dan radikal sehingga hakekatnya di temukan. ${ }^{6}$

Disisi lain filsafat adalah proses kritik atau pemikiran terhadap pemikiran atau sikap yang dijunjung tinggi. Ini adalah arti yang sangat formal dari "filsafat" dua arti filsafat "memiliki dan melakukan" tidak dapat dipisahkan sepenuhnya satu

${ }^{6}$ Sutarjo A Wiramihardja, Pengantar Psikologi Abnormal, (Bandung: Refika Aditama, 2005), 107 
Ach. Syaikhu

sama lainya. ${ }^{7}$

Dari uraian diatas tidak lah heran jika dalam dunia Islam filsafat begitu cepat perkembanganya sehingga banyak lahir tokoh tokoh filsafat dan beberapa pemikiran pemikiranya yang semua itu didasari oleh Al-Qur'an dan Al-Hadits. Teks Al-Qur'an bukanlah monumen mati yang untouchable, yang tidak dapat disentuh oleh tangan sejarah. Sebaliknya ia lahir di ruang tidak hampa untuk merespon segala persoalan kemanusiaan yang terus bergerak dinamis. Denyut nadi Al-Qur'an bisa terus hidup bukab hanya melalui pengembangan mekanisme tafsir, istimbath yang proposional, tetapi lebih dari itu kita mesti mengembangkan dengan pola- pola interelasi antara teks Al-Qur'an itu sendiri dengan elemen ajaran lain yang saling melengkapi menjadi satu kesatuan organis yang hidup dan bergerak dinamis organisme yang hidup ini diharapkan mampu merespon perkembangan manusia yang hidup sesuai tingkat perubahan sosial yang terus terjadi sepanjang sejarah. ${ }^{8}$

Dari kontek inilah dinamika dalam pemikiran Islam terus maju, dinamis dan inovatif sesuai dengan kapasitas serta kebutuan yang dialami oleh manusia sesuai dengan zamannya. Dengan demikian Islam tidak setatis. Karena nilai ajaran Islam sisilain bersifat doktriner yang tidak bisa diubah tapi dalamkontek nilai nilai yang sifatnya sosial bisa beriringan dengan perkembangan sosial yang ada dengan tidak benturan. Agar nilai nilai Islam itu dalam aktualisasinya bisa beriringan dan sejalan dengan ruang serta zamanya maka pemikiran filsafat sangat diperlukan.

\section{Bidang Tasawuf}

Tasawuf adalah tingkah laku dan perasaan; tingkah laku yang menjauhi segala keinginan dan hal-hal yang memesona dan ditujukan demi kesucian jiwa dan tubuh. Perasaan cinta dan bahagia, manakala seorang murid [orang yang berkehendak] mencapai dua kesucian ini. Tasawuf juga berarti amal dan analisa; amal yang berlandaskan pada mujahadah [memerangi hawa nafsu sendiri] dan mujahadah [ketahanan diri menghadapi bencana] pusa di siang hari dan beribadah sunnah di malam hari, mengorbankanjiwa dan harta yang nampak ke dalam alam batin. Akhirnya tasawuf adalah ada dan tiada; tiada bagi orang yang tergesa dan ada bagi orang yang tidak tergesa [mementingkan akhirat, al Ajil]. Tiada bagi orang yang sirna dan ada bagi orang yang kekal, tiada bagi manusia dan ada bagi Tuhan.

\footnotetext{
${ }^{7}$ Beni ahamad Soebani, Filsafat Ilmu, (Bandung: Pustaka Setia, 2009), 115

${ }^{8}$ Abu Yasid, Islam Akomodatif Rekonstruksi Pemahan Islam Sebagai Agama Universal, Yogyakarta, 2004, 134
}

136 | FalASIFA, Vol. 10 Nomor 1 Maret 2019 
Tasawuf secara ringkas adalah mata rantai yang terdiri atas kondisi-kondisi [al-ahwal] dan maqam-maqam, yang satu sama lain saling merupakan anak tangga. Orang yang mau menjadi sufi memulai langkah dengan membersihkan jiwanya, agar bisa menjadi orang yang berhak menerima tajalli [penampakan], selalu meningkat hingga bisa merasakan Allah [ada] di relung jiwanya dan demukian dekat dengan-Nya. Kajian-kajian tasawuf dalam Islam tidak terbentuk sekaligus, tetapi berkembang menembus perjalanan waktu melewati fase-fase tertentu secara bertahap[45].

Tasawuf Islam melewati berbagai fase. Pertama, tampil dalam bentuk ibadah dan zuhud. Disini seseorang meninggalkan dunia dan menuju akhirat serta secara teguh berusaha melakukan hal-hal yang bisa menjadi taat dan dekat kepada Allah. Kaum tasawuf Islam membutuhkan waktu kira-kira dua abad dalam kondisi demikian. Kaum zuhud generasi pertama amat banyak, antara lain al Hasan al Basri [110 H / $728 \mathrm{M}$ ] sebagai tokoh kaum zuhud Basrah, Ibrahim bin Adham [159H / $776 \mathrm{M}]$ sebagai tokoh zuhud Balkh, dan Rabi ah al Adawiyyah sebagai tokoh kaum zuhud wanita.

Dalam beribadah kebanyakan kaum sufi pada fase ini mencari tempattempat yang terisolir dari manusia. Tasawuf kemudian nyaris tidak keluar dari bentuk tingkah laku [al suluk] dan kemampuan amaliah, yang ditujukan untuk menyucikan jiwa dan tubuh. Pada fase ini juga tasawuf tidak banyak mementingkan kajian atau studi, di samping tidak berusaha meletakkan teori maupun penyebaran pikiran.

Pada fase kedua, kaum sufi mulai melakukan kajian teoritis. Untuk itu, pertama-tama mereka berorientasi pada jiwa untuk disingkapkan rahasiarahasianya, dijelaskan segala kondisi dan maqamnya. Sebagai bukti, mereka membicarakan tentang keasyikan dan kerinduan, takut dan harapan, cinta dan emosi, tiada dan ada, fana' dan kekal. Mereka mencari cinta ilahi di mana saja bisa ditemukan. Mereka membicarakan pemecahan terhadapbanyak masalah, mirip dengan kajian-kajian psikologis.

\section{KESIMPULAN}

Pemikiran Islam adalah pemikiran yang khas, lain daripada yang lain. Sebab pemikiran Islam berasal dari wahyu atau bersandarkan pada penjelasan wahyu, sedangkan pemikiran-pemikiran yang lain yang berkembang di antara manusia, baik itu berupa agama-agama non samawi, ideologi-ideologi politik dan ekonomi, maupun teori-teori sosial sekedar muncul dari kejeniusan berfikir manusia yang melahirkannya. Perkembangan Awal Pemikiran Islam. Proses pembentukan pemikiran itu diawali dengan peritiwa-peristiwa, misalnya ada persentuhan 
Ach. Syaikhu

pendapat, agama, kebudayaan atau peradaban antara satu dengan lainnya. Persentuhan tersebut terkadang menimbulkan bentrokan atau akulturasi bahkan tidak jarang terjadi asimulasi. Proses perkembangan pemikiran muslim, terdapat dalam tiga fase dan erat kaitannya dengan sejarah Islam. Dinamika Pemikiran Islam terdiri dari : 1. Bidang Kalam [Teologi], 2. Bidang Fikih, 3. Bidang Filsafat,

\section{DAFTAR PUSTAKA}

Djakfar, Muhammad, 2010, Teologi Ekonomi Membumikan Titah Langit di Ranah Bisnis, (Malang; UIN Malang)

Ihsan, Hamdani, 2010, Filsafat Pendidikan Islam, (Bandung; Pustaka Setia)

Mujtaba, Saifuddin, 2012, Ilmu Fiqih Sebuah Pengantar, (Jember; STAIN Jember Press)

Nizar, Samsul, 2013, Sejarah Pendidikan Islam , (Solo; Kencana Prenada Media Gurp)

Soebani, Beni ahamad, 2009, Filsafat Ilmu, (Bandung: Pustaka Setia)

Soekarno dan Ahmad Supardi, 2001, Sejarah dan filsafat pendidikan Islam, (Bandung; Angkasa)

Wiramihardja,Sutarjo A, 2005, Pengantar Psikologi Abnormal, (Bandung: Refika Aditama)

Yasid, Abu, 2010, Islam Akomodatif Rekonstruksi Pemahan Islam Sebagai Agama Universal, Yogyakarta 